\title{
The development of policy actors involved in the Bologna reform in Ukraine
}

\author{
Dr Iryna Kushnir \\ Nottingham Institute of Education \\ Nottingham Trent University \\ Nottingham, United Kingdom \\ NG11 8NS \\ E-mail: iryna.kushnir@ntu.ac.uk
}

\begin{abstract}
The Bologna Process is an international policy project for the convergence of higher education structures in the European Higher Education Area. Most of the literature on Bologna represents studies that focus on the implementation implications of the reforms. The focus on the reform process, particularly in relation to the development process of Bologna policy actors, has been under-represented in the literature. This article investigates the process of the development of the main policy actors involved in the Bologna reform in the case of Ukraine. The timeframe includes the pre-history of Bologna since Ukrainian independence in 1991 until after the introduction of the relevant policy changes in 2003, and through to the issue of 2014 Law on Higher Education. Empirical data were collected through interviews with higher education actors in Ukraine and policy document search. Both types of data were thematically analyzed. The analysis in this article is informed by the policy learning theory and demonstrates the interconnection between path-dependency and change in the development of policy actors in the Bologna reform in Ukraine. This article shows that the old clusters of higher education actors, and the pre-Bologna relationships amongst some of them have been reproduced during the Bologna reform. At the same time, such a reproduction of the old during the reform was only partial as the Bologna Process has also been altering the relationships among some actors to an extent.
\end{abstract}




\section{Introduction}

The Bologna Process, or Bologna, started in 1999 when representatives from 29 European countries signed the "Bologna declaration" (1999) in which they proclaimed their intention to build the European Higher Education Area (EHEA) through the convergence of higher education systems. The main goal was to enhance academic and job mobility in the EHEA. Higher education representatives who signed the "Bologna declaration" in 1999 also called upon other nearby countries to join the Bologna Process. Apart from the general goal to create the EHEA, a few specific objectives, called the action lines, were identified, such as the adoption of a common system of credits and cycles of study process, the development of an easily readable diploma supplement issued to graduates, the facilitation of student and academic staff mobility and the assurance of higher education quality (European Higher Education Area, 2014).

Ukraine officially joined the Bologna Process in 2005 ("Bergen communique,” 2005). The general context of Ukraine is characterized by its strong path-dependency - dependency on the Soviet legacies (Kuzio, 2012) - and, at the same time, the drive for change (Wolczuk, 2009). Thus, the way in which path-dependence and change intertwine in the Bologna Process is an interesting subject for research.

This article looks specifically at the process of the development of the main policy actors involved in the Bologna reform in Ukraine. The emphasis on the process of the development of policy actors and their relationships is under-developed in the Bologna literature both in different national contexts, as well as specifically in Ukraine. This is because most of the literature on the Bologna Process represents studies that look at the extent to which Bologna action lines have been implemented, as well as successes and failures in this process (Kushnir, 2016).

The analysis in this article is informed by the policy learning theory as conceptualized 
by Thelen (2003). This author critiques the earlier generation of policy studies that discus path-dependence and policy change as opposing forces that are at conflict. Thelen (2003) recognises that the punctuated equilibrium model served as the first step towards the emergence of the new analytical perspective that would position path-dependency and change as interconnected in policy process. The punctuated equilibrium model states that there are brief moments of openness of policy establishments to the acknowledgement of new ideas. Such moments are followed by an adherence to past conventions. Thelen (2003) further states that there is a need to develop a new approach that would use punctuated equilibrium as a stepping stone to the idea that path-dependency and change are not opposing forces at all. This new approach would advocate the idea that they can conflate with each other in policy development. This is what Thelen (2003) sees as the new age of policy learning.

Empirical findings of this article rely on Thelen's (2003) policy learning idea and demonstrate the interconnection between path-dependency and change in the development of policy actors in the Bologna reform in Ukraine. This article shows that the old clusters of higher education actors, and the pre-Bologna relationships amongst most of them have been reproduced during the Bologna reform. At the same time, such a reproduction of the old during the reform was only partial. The Bologna Process has also been changing the Ukrainian higher education system by altering the relationships among some actors to an extent.

\section{Bologna in National Context}

The studies about Bologna in different national contexts can be roughly divided into two groups. One of them consists of a plethora of studies that evaluate the extent to which the action lines have been implemented in the countries. The other group looks at how the process of Bologna reform has proceeded. It is, however, a relatively small group of studies, and thus, 
the process of Bologna reform, particularly with reference to the development of policy actors involved in the reform, needs more analysis.

\subsection{Implementation implications}

The most 'populated' body of literature includes numerous small-scale single country and comparative studies. They look at the extent to which the action lines have been implemented in various Bologna countries. They tend to provide a brief chronology of important milestones in the national reforms as a background of the research. The main emphasis, however, is on the achievements and failures in the implementation of the action lines. The queries that guide these studies could be summarized in such questions: whether Bologna is a 'bridge or fortress' (King, undated: p.1), or whether it is a 'motor or stumbling block' (Teichler, 2012: p.3) for the development of higher education systems in the countries.

The success of the Bologna reforms is demonstrated in the literature in terms of a number of issues. Cocosatu (2012) explains that the introduction of the diploma supplement a document issued to all graduates in addition to the degree certificate - made the information about different types of higher education institutions in Romania explicit, and that this information enhances students' prospects for further studies or employment. The effects of the development of the diploma supplement in Russia are explored in another study (Esyutina, Fearon, \& Leatherbarrow, 2013). They are regarded as generally positive as well. Some wider positive implications of Bologna are perceived to be the case in, for instance, Poland, Italy, Spain and Armenia. Specifically, in Poland, Bologna has increased the autonomy of universities in their decision-making process. It has also opened them up to the market economy (Dakowska, 2015). In Italy and Spain, Bologna has increased higher education efficiency. According to Agasisti and Pérez-Esparrells (2010), efficiency is the relation of the produced output to the amount of input, often measured as public funding investment. The study shows that Italian universities became more efficient than those in Spain. Higher 
education efficiency in Italy has been facilitated by structural reforms such as the cycles of studies. In Spain, efficiency has been facilitated by the introduction of new funding models for quality assurance in higher education. Furthermore, in Lithuania, Bologna was a tool to facilitate students' inward and outward mobility which, in turn, made Lithuanian higher education more international and enriching (Karveliene, 2014). Lastly, Melikyan (2011) dwells on educational reforms in Armenia and emphasizes that joining Bologna brought about the modernization of the negative post-Soviet situation.

The examples of the cases when the Bologna action lines could not have been implemented 'properly' are the following. Pyykkö (2008) and Esyutina, Fearon and Leatherbarrow (2013), for instance, investigate the problems of fitting the Specialist's degree, common in the post-Soviet area, into the Bologna three-cycle system. Both studies acknowledge that the difficulty lies in the fact that it is an additional degree which is higher than Bachelor's and lower than Master's. In Russia, Azerbaijan and Kazakhstan, for instance, it was treated as part of the first cycle in addition to the bachelor's degree (Pyykkö, 2008). Further, the challenges associated with the recognition of the information in the diploma supplement by employers in Russia is analyzed by Esyutina, Fearon and Leatherbarrow (2013).

There is also a couple of studies that emphasize a common problem of bureaucratic reforms - a lack of real substance. One study explores the results of the reform of the twocycle study system, quality assurance, accreditation and mobility promoting measures in the Netherlands and in Flanders - a Dutch-speaking region of Belgium (Dittrich, Frederiks, \& Luwel, 2004). The authors maintain that little has been changed in terms of the content of higher education in both regions, although some structural changes have taken place. For instance, some universities implemented the two-cycle study system by simply breaking down their old single four or five-year programmes into two. The other study points out a similar 
problem in the contexts of Romania and Austria (Wodak \& Fairclough, 2010).

Clearly, these studies are focused on the effects of the reform process. They see contextual features as an obstacle for Bologna in various countries, including those in the post-Soviet region. Viewing the context as a barrier is typical in this literature. My research does not evaluate path-dependency as an obstacle. It looks at it as a force which is as productive as innovative ideas in the reform process.

\subsection{The process of the reform}

Besides the scholarly literature that discusses the success and problems that have resulted from the higher education reforms in the Bologna countries, there is another body of literature about Bologna in the national contexts. It looks at the process of the Bologna reform. It is a small body of literature to which my research aims to contribute. All of these studies look at slightly different issues related to the reform process, as some examples below demonstrate.

Jakobi \& Rusconi (2009) focus on how the lifelong learning initiative has been developed in a group of countries that signed "the Sorbonne declaration" in 1998 - the United Kingdom, Germany, Italy and France. The study analyses state documents from these countries as well as empirical data about participation rates by age and year, taken from the databases of the UNESCO Institute for Statistics, the Organization for Economic Cooperation and Development, and Eurostat. These data allowed the authors to analyze chronologically the developments associated with lifelong learning in the four countries. The study concludes that lifelong learning has been developed by different strategies in these countries.

There are two more studies that look at the implementation of the action lines, but they consider a range of them (Witte, 2006; Cusnir, 2008). In addition, these studies analyze the organization of higher education at higher education institutions in general. These two studies are much bigger in their scope. 
Similarly to Witte (2006), Dobbins and Khachatryan (2015) take a wider perspective by looking beyond the implementation of the action lines. The authors investigate how the models of higher education governing developed in Bologna in the context of other political innovations.

The process of the Bologna reform seems to be viewed as the implementation of change which does not go smoothly because of the past conventions. The gap in research into the process of the Bologna reform in different national contexts is about considering that the past might be a molder of the reforms rather than only a barrier. My study will analyze one facet of the process of the higher education reform by focusing on the development of policy actors that are involved in the reform in the case of Ukraine.

\section{Ukrainian context}

Ukraine, like other post-Soviet countries, obtained its independence relatively recently, in 1991, after the fall of the Soviet Union. The Soviet Union was based on the ideas of Marxism-Leninism, which put centralization, controlled productive force, censorship, compulsory patriotism, and isolation from the Western world at the core of the development of the centrally planned economy (Bridge, 2004).

After the fall of the Soviet Union, all post-Soviet countries have been transforming 'from an empire to a nation, from a command economy to a market-based one, and from a communist to a democratic system' (Tsygankov, 2007: p.425, citing Bunce, 1995). However, the legacy of the Soviet influence is apparent in all areas of life in post-Soviet countries, according to Malle (2009). Post-Soviet Ukraine is characterized by its strong contextual pathdependency and, at the same time, the drive for change. These tendencies have been obvious from the political events in Ukraine in recent years. At the beginning of independence, the political authorities declared that the development of Ukraine would follow a European 
direction and that Ukraine would join the EU (Browning \& Christou, 2010; Wolczuk, 2009). Ukraine has been cooperating with the EU in different policy areas, but it has not yet applied for membership in the EU.

The issues around the European direction of development of Ukraine have gained momentum in recent international political and media debates. The confrontation between the pro-European and pro-Russian supporters on the territory of Ukraine has been growing and was expressed in the 'Orange revolution' in 2004 and the 'Euromaidan revolution' in 20132014.

The Orange and Euromaidan Revolutions aimed to support the European direction of development in Ukraine. Specifically, the Euromaidan Revolution aimed to achieve closer trade connections between Ukraine and the EU, the overthrow of the pro-Russian political elites in the Ukrainian central bodies of governing that have been there since the preindependence time, and membership of Ukraine in the EU. Russia's response to the Euromaidan Revolution and Yanukovych's overthrow was its annexation of the Crimea and military intervention and aggression in eastern Ukraine.

The way in which this political polarization works in the Bologna reform has not been the emphasis in the literature on Bologna in general and specifically in the Ukrainian context. The literature on the Bologna process in Ukraine echoes the foci of Bologna studies in other national contexts - mainly the implication for its implementation. Implementation studies postulate that the success of the Bologna Process in Ukraine is obstructed by: a strict centralization of higher education (Andreichuk, 2007); scarce resources; brain drain (for example, to Poland - https://www.theguardian.com/world/2019/apr/18/whole-generationhas-gone-ukrainian-seek-better-life-poland-elect-president) that results from students' outward mobility and their unwillingness to return to a weak socio-economic situation in Ukraine; overall substantial difference between the inherited Soviet model of education in 
Ukraine and the Bologna policy lines (Telpukhovska, 2006; Kovtun \& Stick, 2009;

Pshenychna, 2009; Shaw, 2013). There are also a few studies that mention policy process as their priority (Shestavina, 2004; Filiatreau, 2011; Luhovy and Kalashnikova, 2014; Kovacs, 2014). However, their focus in usually on the chronological development of events, rather than on the analysis of a policy process. These studies also do not focus on the development of policy actors in the Bologna reform, which is the focus of my research.

The above cited research positions path-dependence as an obstacle for the reforms, rather than a force that gradually shapes higher education together with some innovative ideas. In contrast, this study examines the process of development and evolving role of higher education actors in shaping the Bologna instruments. This focus has been missing from research to date.

\section{Researching Higher Education Actors in Ukraine}

The data informing this article were collected in the framework of a larger project focused on different aspects of policy learning in the Bologna reform in Ukraine which was analyzed as a case of post-Soviet Europeanisation. The larger project was a qualitative study, consisting of policy analysis and interviews, including elite interviews, in Ukraine. Ethical approval was received from the University of X Ethics Committee for conducting interviews. In total, 43 semi-structured interviews were conducted and 88 policy documents collected. Most of the data used in this study were collected between November-December, 2013. However, one document - "Law about Higher Education" (2014) - was collected a year later after that. This Law was passed after the main data collection had been finished, but it was very important for the analysis given its legislative power. These data pertain to the time span that encompasses higher education developments in Ukraine right after its independence in August 1991 up until the issue of the new Law regarding higher education in April 2014. The 
developments after the beginning of the Bologna pilot project in Ukraine in 2004 were looked at in more detail.

This article provides exemplary quotations from seven out of the 43 semi-structured interviews with higher education actors (including representatives from the central governing bodies, different types of organizations, academic staff members at universities - see Appendix 1), and considers directly 25 out of the 88 policy documents (Appendix 2).

The data from the interviews and policy documents were thematically analyzed following Rubin and Rubin's (2012) guide. The first stage of this process was open coding. It involved reading through the interview transcripts and documents to identify broad codes and then rereading the transcripts to specify them. The open coding was conducted with the following questions in mind: 'what was developed in terms of the study cycles', 'who participated in this process', 'when did the developments take place', 'why did they take place' and 'how did they take place', following Dolowitz and Marsh's (2000) idea of a multifaceted study of policy learning. The question 'who participated in this process' was the most important for this article. The second stage of coding was axial coding, according to Rubin and Rubin (2012). It entailed reading through the codes multiple times to reveal relationships between them. In this study, these relationships among the categories obtained after the open coding were primarily shaped by the theoretical framework rooted in the idea that pathdependency and layering may play a key role in the process of policy learning.

\section{The development of higher education actors in Ukraine}

This section focuses on the most active representatives from two key clusters of policy actors - central governing bodies (the Ministry of Education and Science) and civil sector organisations (the National TEMPUS/ERASMUS Plus Office).

\subsection{The Ministry of Education and Science}


After Ukraine obtained its independence in 1991 following the collapse of the Soviet Union, it experienced difficulties in moving away from the centralized control in higher education, like in all other aspects of public administration (Jones, 2000). At the outset of the Ukrainian independence, the central policy-making bodies specifically in higher education also included the President, the Parliament, and the Government. It is also worth mentioning that the Government consists of different ministries. The Ministry of Education and Science and a few other ministries cooperated with one another in governing higher education in certain areas (Kremen et al., 2006; Andreichuk, 2007; Pshenychna, 2009).

The roles of these actors in higher education were associated with their general responsibilities in relation to the three branches of state power: legislative, executive and juridical. According to the "Constitution of Ukraine" (1996), the Government executed legislation, enacted by the Parliament under the supervision of the President. The Ministry of Education and Science was primarily responsible for day to day matters of higher education and functioned as the point of contact between the central governing bodies and higher education institutions (Kremen et al., 2006).

The findings of this research show that all of these actors in the central governing bodies have remained formally involved in the higher education matters in Ukraine throughout the Bologna Process. The findings also show that the Ministry of Education and Science has been gaining more power in directing the development of higher education in the course of implementing the Bologna action lines. At the same time, the Ministry has been gradually allowing itself a degree of cooperation with other clusters of actors. The main roles of all of the central governing actors in Bologna, found out during this research, are summarized in Table 1. The role of the Ministry of Education and Science is discussed in greater detail below.

Table 1: Central Governing Bodies and Their key Roles in the Bologna Process 


\begin{tabular}{|c|c|}
\hline Actor & Main Functions in the Bologna Process \\
\hline President & $\begin{array}{l}\text { - Following the Congress of Education Policy-makers, organised by } \\
\text { the Ministry of Education and Science, the President confirmed the } \\
\text { National Doctrine of Education Development ("Presidential order } \\
\text { №347," 2002). The aim to integrate into 'the European education } \\
\text { space' was outlined in this Doctrine. }\end{array}$ \\
\hline Parliament & $\begin{array}{l}\text { - The Parliamentary Committee of Education and Science Matters } \\
\text { participated in the production of four out of seven drafts of the new } \\
\text { law regarding higher education to legalise some Bologna principles } \\
\text { (№9655-1, 2011; №9655-2, 2012; №1187-1, 2013 and №1187-2, } \\
\text { 2013). } \\
\text { - The same Committee initiated one Bologna related correction in the } \\
\text { old "Law about Higher Education" before the passing of the new } \\
\text { Law in 2014. The correction was related to expanding the scope of } \\
\text { students" self-government. Students were granted the right to } \\
\text { participate in the confirmation of the membership of the Scientific } \\
\text { Councils at institutions ("Law about Higher Education," 2002, } \\
\text { correction №9, 2010). }\end{array}$ \\
\hline $\begin{array}{l}\text { Government } \\
\text { headed by the } \\
\text { Prime Minister }\end{array}$ & $\begin{array}{l}\text { - Following the commencement of the Bologna pilot, the Prime } \\
\text { Minister initiated the creation of the Interdepartmental Commission } \\
\text { for the Support of the Bologna Process in } 2004 \text { ("Governmental } \\
\text { resolution №1131," 2004). In 2006, the Prime Minister also initiated } \\
\text { changes in membership at the Interdepartmental Commission - it } \\
\text { previously included only representatives from different Ministries } \\
\text { ("Governmental resolution №82," 2006). This Commission was } \\
\text { cancelled in } 2013 \text { ("Governmental resolution №180," 2013). } \\
\text { - The Prime Minister initiated the creation of a working group to } \\
\text { develop the national qualifications framework - a Bologna } \\
\text { instrument (e.g., "Governmental resolution №1225," 2010). }\end{array}$ \\
\hline $\begin{array}{l}\text { - Ministry of } \\
\text { Education } \\
\text { and Science }\end{array}$ & $\begin{array}{l}\text { - The Minister and three other Ministerial representatives attended the } \\
\text { Bologna international conference in } 2003 \text { as observers. Afterwards, } \\
\text { the Minister initiated the Bologna pilot project which lasted from } \\
2004 \text { to } 2008 \text { ("Ministerial decree №48," 2004). } \\
\text { - The Ministry signed the official membership of Ukraine in the } \\
\text { Bologna Process in } 2005 \text { ("Bergen communique," 2005). } \\
\text { - The Minister initiated the implementation of most of the Bologna } \\
\text { instruments. } \\
\text { - The Ministry initiated and controlled the production of drafts for the } \\
\text { new Law regarding higher education. }\end{array}$ \\
\hline $\begin{array}{ll}\text { - } & \text { Other } \\
\text { Governmen } \\
\text { t Ministries }\end{array}$ & $\begin{array}{l}\text { - Several ministries were responsible for specialised institutions (e.g., } \\
\text { the governing of medical institutions by the Ministry of Health Care) } \\
\text { and cooperated with the Ministry of Education and Science during } \\
\text { the Bologna Process. } \\
\text { - Other ministries (e.g., External Affairs, Economics, Finance, Justice, } \\
\text { Culture and Tourism, Agrarian Politics, Internal Affairs, and Health } \\
\text { Care) were formally included in the membership of the } \\
\text { Interdepartmental Commission mentioned above. However, the } \\
\text { findings of this research suggest that this Commission was a non- } \\
\text { functioning actor. }\end{array}$ \\
\hline
\end{tabular}


- The ministries of Justice, Internal Affairs, and Economics participated in agreements for international cooperation in higher education and diploma recognition ("Law about International Agreements," 2004).

The Ministry of Education and Science did most out of all central actors to introduce and further support Bologna in Ukraine. It coordinated the All-Ukrainian Congress of Education Policy-makers and Academic Managers of Higher Education Institutions in 2001 (Kremen et al., 2006). During the Congress, consensus was reached about the plan for Ukraine to join the European Higher Education Area (EHEA) and Europeanize Ukrainian higher education. The National Doctrine of Education Development, adopted at the Congress, was later confirmed by the President ("Presidential order №347," 2002). The aim to integrate into 'the European education space' was outlined in that Doctrine.

Further, the-then Minister of Education and Science with three other ministerial officials attended the international EHEA ministerial conference in 2003 as observers ("Berlin conference," 2003). None of these individuals were available for interviews during data collection, so the logic behind their subsequent actions can only be speculated. Nevertheless, the representatives of the Ministry who were interviewed suggested, for instance, that

It was important to show the world that we wanted to keep up the pace with other countries and implement Bologna. The best way to show that was to start implementing it. We tried it through the pilot project. It went well, and we joined the Bologna Process in 2005 (i.6).

The Ministry initiated the Bologna pilot project in Ukraine at 59 universities in 2004 (“Ministerial decree №48,” 2004). This was done to meet the eligibility criteria for the EHEA membership application. It was stated in the communique of the Berlin conference that 'countries party to the European Cultural Convention shall be eligible for membership of the EHEA provided that they at the same time declare their willingness to pursue and implement the objectives of the Bologna Process in their own systems of higher education' ("Berlin communique,” 2003: p.8). Ukraine had already ratified the European Cultural Convention 
back in 1994. This event was positioned as a step to demonstrate Ukraine's willingness to join the European Union (EU) (“Parliamentary resolution №27," 1994). However, the ratification of the European Cultural Convention generally means agreement to adhere to the European values of democracy and the rule of law. Besides, in order to fully qualify for the EHEA membership application, it was also necessary to declare the willingness of Ukraine to pursue the Bologna principles. The Bologna pilot project that the Ministry arranged was apparently the way in which the Ministry demonstrated such willingness.

The pilot project presupposed the introduction of a number of initiatives quite quickly. They included: the implementation of the credit-module system; the creation of the recommendations for the improvement of the cycles of the study process; the development of higher education standards; the development of the diploma supplement, and some others. These examples will be discussed in detail later. However, what is important here is that the overarching aim of all of them was the Europeanisation of higher education. According to the pilot project timeline, all the tasks should have been fulfilled within one year - by the end of 2004. It marked the end of the first phase of the pilot project. The second phase of the pilot was supposed to last till 2008 and to be dedicated to making corrections and improvements in the initiatives (“Ministerial decree №48," 2004 and “Ministerial decree №49," 2004). The pilot project, primarily its first phase, was characterized by active document production by the Ministry:

... a pile of state documents appeared - mainly decrees of the Minister, but also some resolutions of the Cabinet of Ministers... This phase lasted up to, I think, 2005-2006. There are a lot of such documents (i.5, current academic manager at a university, ex-member of the Parliamentary Committee of Education and Science Matters).

One of the documents that the Ministry produced was a "National Bologna Implementation report" (2004). The Ministry submitted it to the Bologna Secretariat, most likely along with the application for the membership of Ukraine in the EHEA. Ukraine 
officially joined the Bologna Process at the EHEA international conference in 2005 in Bergen ("Bergen communique," 2005). This is the justification for joining Bologna by Ukraine, provided by an ex-worker of the Ministry:

The Bologna principles have been important for us. The Bologna Process has been targeting the achievement of transparency in educational systems of different countries and comparability of their degrees and qualifications. It presupposes the modernization of our old higher education system and a necessary step towards the EU... of the Ukrainian society... Ukraine chose the European direction of development long time ago (i.7, current academic manager at a university, ex-representative of the Ministry).

This is a vivid example of how Europeanisation discourse focused on Ukraine joining the EU has been used by the Ministry to justify its work towards Bologna, and how Bologna is positioned by the Ministry as part of Ukrainian movement towards eventually joining the EU.

The Minister and the Ministerial Department of Higher Education, that seem to have been the most central in the work of the Ministry on Bologna, demonstrated little consideration of the opinions of other actors in the development of Bologna. While little consideration has been made, the Minister and the Department of Higher Education (usually jointly referred to as the Ministry throughout this article) did engage in some sort of cooperation with other actors in the Bologna Process. The first case of it was the AllUkrainian Congress of Education Policy-makers and Academic Managers of Higher Education Institutions, where it was agreed that the Bologna Process should be introduced in Ukraine. In another example, the Ministry also cooperated with other actors in Bologna is through the participation in working groups. Their purpose is to develop Bologna instruments (e.g., “Governmental resolution №1225,” 2010).

Finally, the Ministry also cooperated with other clusters of actors to produce a draft Law regarding higher education. The Ministry initiated the creation of the first draft ("Draft law №7486-1,”2010), which was meant to be adopted as a new Law about Higher Education 
in substitution for the old Law (2002). It was necessary to legalize the innovations, for instance, the credit system, that had already been implemented by the Ministry through its decrees. The new Law was also necessary to introduce some innovations related to, for example, state funding of higher education. The first Ministerial draft, however, faced strong opposition from institutions, non-state organizations, and the-then political opposition which was a minority in Parliament. They opposed state funding cuts for higher education institutions (Smyrnov, 2013).

Consequently, five more drafts were produced separately by the Ministry, the political opposition in Parliament, and a deputy from the majority in Parliament (see Table 2 below). The analysis of these drafts demonstrates that all of them came to similar conclusions about many Bologna instruments that had already been introduced by the Ministry in its decrees during and after the Bologna pilot. These drafts differed, however, in their perspective on how to fund higher education institutions. The drafts were produced one after another, creating a scene of battle between the two suggestions. One of the suggestions was to either keep the old arrangements of funding institutions from the state budget, or to slightly reduce the amount of funding. The other suggestion - from the Ministry and a deputy from the majority party in Parliament - was to significantly reduce state funding for institutions. It was suggested in order to promote institutional autonomy in looking for the sources of funding. There was no consensus between the majority in Parliament, which was also supported by the Government and the Ministry, and the minority in Parliament. The anxiety from institutions surrounding the prospect of funding cuts triggered public resistance which took the form of public street demonstrations and written petitions to the Ministry to denounce the drafts that could lead to the reduction of funding (Smyrnov, 2013).

Table 2: List of Draft Laws

\begin{tabular}{|l|l|c|}
\hline $\begin{array}{l}\text { Draft Law } \\
\text { (№) }\end{array}$ & $\begin{array}{l}\text { Date of Registration in } \\
\text { Parliament }\end{array}$ & Main Initiators \\
\hline
\end{tabular}




\begin{tabular}{|l|l|l|}
\hline $7486-1$ & 22.12 .2010 & The Ministry which? \\
\hline 9655 & 28.12 .2011 & The Ministry which? \\
\hline $9655-1$ & 30.12 .2011 & $\begin{array}{l}\text { Political opposition in the Parliament Wich } \\
\text { factions? }\end{array}$ \\
\hline $9655-2$ & 06.01 .2012 & $\begin{array}{l}\text { Deputy, who is a supporter of the majority in the } \\
\text { Parliament Who? }\end{array}$ \\
\hline 1187 & 28.12 .2012 & The Ministry which? \\
\hline $1187-1$ & 11.01 .2013 & $\begin{array}{l}\text { Political opposition in the Parliament Which } \\
\text { factions? }\end{array}$ \\
\hline $1187-2$ & 21.01 .2013 & Cross-cluster group \\
\hline
\end{tabular}

These disagreements finally motivated the Ministry to create a diverse group consisting of representatives from different clusters of actors to reach a common consensus. A resulting draft (№1187-2, 2013) was eventually passed as the new Law in 2014.

These findings demonstrate that centralization in most of the work carried out by the central cluster continued, while some other aspects of its work underwent changes in the Bologna context. These central actors, having existed before Bologna, continue to play a crucial role in steering higher education developments in Ukraine. However, the relationships existing within the central governing bodies have continued to evolve following the increase of the directive power of the Ministry. At the same time, the Ministry has been gradually allowing itself a greater degree of cooperation with other actors beyond the central governing bodies - mainly with the that represents the so-called 'civil sector'.

\subsection{The National TEMPUS/ERASMUS Plus Office}

The civil sector - mainly non-governmental organizations - existed before the Bologna Process. The civil organizations are recognized in the literature as a cluster. The literature about Ukrainian policy-making states that a cooperation gap used to exist between the central bodies of policy-making and civil organizations (Protsyk, 2003).

The members of the non-governmental organizations referred to themselves as the 'civil sector' in the interviews conducted in this research. Such a name stems from the idea that 
these actors are organized due to their own efforts with no assistance from the central governing bodies. This research suggests that the civil sector is the most populated cluster in Bologna ahead of the higher education institutions. The civil sector involves the greatest number of actors in the Bologna reform as compared to the other clusters. My research demonstrates that differences exist between the roles played by the actors within the civil sector cluster in Bologna. Thus, they could be categorized into three groups (see Table 4).

Table 4: Civil Sector Actors and Their Functions in the Bologna Process

\begin{tabular}{|c|c|c|}
\hline Group & Examples of Actors & Roles \\
\hline 1 & $\begin{array}{l}\text { Fund Vidrodzhennya, Democratic } \\
\text { Initiatives Foundation, the Ukrainian } \\
\text { Association of Students' Self-Government, } \\
\text { the Trade Union of Education and Science } \\
\text { Workers of Ukraine, the Centre of } \\
\text { International Projects Euro Education, } \\
\text { Organization Institute of Leadership, } \\
\text { Innovation and Development, the System } \\
\text { Capital Management Group, the Rector's } \\
\text { Council, the Confederation of Employers, } \\
\text { UNESCO departments, All-Ukrainian } \\
\text { Academic Union, International Association } \\
\text { of Trade and Economic Education, etc. }\end{array}$ & $\begin{array}{l}\text { This group contains establishments } \\
\text { which have a wide scope of } \\
\text { interests, including higher } \\
\text { education. They, at some point, } \\
\text { started learning about Bologna and } \\
\text { contributing to its development. } \\
\text { For example, Democratic } \\
\text { Initiatives Foundation, has many } \\
\text { objectives including but not limited } \\
\text { to higher education issues - } \\
\text { monitoring exit-polls during } \\
\text { political elections, conducting } \\
\text { sociological investigations, } \\
\text { informing the public on political } \\
\text { processes, etc. (Fund } \\
\text { 'Demokratychni Initsiatyvy,' } \\
\text { 2015). }\end{array}$ \\
\hline 2 & $\begin{array}{l}\text { Offices of European organizations such as } \\
\text { the British Council, European Fund of } \\
\text { Education, the German program DAAD, } \\
\text { the EU Delegation in Ukraine. In addition, } \\
\text { there are even offices of several American } \\
\text { organizations and programs such as USAD, } \\
\text { Fulbright, IREX, Peace Corps that are } \\
\text { claimed by interviewees to contribute to } \\
\text { Bologna in Ukraine by supporting } \\
\text { academic mobility. }\end{array}$ & $\begin{array}{l}\text { This group contains offices of } \\
\text { foreign organizations in Ukraine } \\
\text { that support Ukrainian higher } \\
\text { education but do not always } \\
\text { explicitly state that they are } \\
\text { engaged with Bologna. Most of } \\
\text { these organizations are subordinate } \\
\text { structures of other international } \\
\text { establishments that are not } \\
\text { formally recognized as Bologna } \\
\text { consultative members. }\end{array}$ \\
\hline 3 & $\begin{array}{l}\text { The National Bologna Centre and the } \\
\text { National TEMPUS/ERASMUS Plus } \\
\text { Office. }\end{array}$ & $\begin{array}{l}\text { This group includes two } \\
\text { organizations that emerged } \\
\text { specifically to deal with the } \\
\text { Bologna Process in Ukraine. }\end{array}$ \\
\hline
\end{tabular}


Below is the analysis of the National TEMPUS/ERASMUS Plus Office as a case of change in the structure of policy actors in Ukraine in Bologna and the change of their relationships. I will demonstrate that the tendency for a cooperation gap to exist between the central governing bodies and the civil sector mentioned by Protsyk (2003) has been preserved to an extent during the reform as well. However, this gap narrowed as a result of the cooperation specifically between the Ministry and the National TEMPUS/ERASMUS Plus Office.

The National TEMPUS/ERASMUS Plus Office had its pre-history as the international TEMPUS Program before it emerged as an actor in Bologna. The international TEMPUS Program aimed 'to support higher education modernization in the Partner Countries of Eastern Europe, Central Asia, the Western Balkans and the Mediterranean region, mainly through university cooperation projects' (EACEA, 2015). Ukraine joined this program in 1993. Obviously, this preceded the Bologna Process.

The office of the TEMPUS Program continued to support the modernization of the Ukrainian higher education after the country joined Bologna. It has done so by providing financial and informational assistance to higher education institutions. This assistance was meant to aid in the adjustments of institutions to the new structure of study cycles, implemented by the Ministry (EACEA, 2015). Thus, the office of the Program was not an actor that emerged specifically to support the Bologna Process.

The National TEMPUS Office in Ukraine emerged in 2009 on the basis of the TEMPUS Program to deal specifically with the Bologna Process. The creation of the National TEMPUS Offices in the Bologna countries was an initiative of the Education and Culture Department of the European Commission. The Commission cooperated with the Institute of Leadership, Innovation and Development, which is a civil sector organization in Ukraine. 
This cooperation resulted in the creation of the National TEMPUS Office (National TEMPUS Office, 2009). The National TEMPUS Office, according to its website, intended to coordinate cooperation among a number of higher education actors in Ukraine, such as the Delegation of the EU in Ukraine, the Ministry, higher education institutions and other interested parties (National TEMPUS Office, 2009).

The National TEMPUS Office managed to achieve some sort of cooperation with the Ministry. Appraisal of the impact of the work that has been done by the National TEMPUS Office in cooperation with the Ministry and other actors is obvious from the following quote. It illustrates the main difference in the work of the National TEMPUS Office and the actor discussed earlier - the National Bologna Centre:

The Bologna Process was developing a bit slowly in Ukraine. It speeded up after 2009, according to our observation... We see the dynamics of changes associated with the Bologna Process. People used to be far more ignorant about what the Bologna Process was... and there used to be far more negative evaluations of the Bologna Process. There is a tendency for improvement now. More people understand and support Bologna largely due to our work (i.4, National TEMPUS Office representative).

Indeed, the time after the creation of the National TEMPUS Office was marked by, for instance, the issue of "Ministerial decree №943" (2009). The decree was related to improving the credit system in Ukraine. The National TEMPUS Office made significant contributions to raise awareness about the Bologna Process in Ukraine. This might be a reason why a large number of the representatives from different Bologna Process clusters of actors in Ukraine are aware of the National TEMPUS Office in some capacity:

The words 'TEMPUS' and 'TEMPUS Office' are always common among students and staff members, especially those who deal with all these academic mobility issues (i.1, university academic staff member).

I will illustrate how the National TEMPUS Office has been facilitating cooperation in Bologna using an example of the team of the Higher Education Reform Experts (HEREs). 
The team has been functioning within the TEMPUS Office since its inception. Many of the initiatives of the National TEMPUS Office are co-facilitated by the HEREs. Meetings of the HEREs are often held to discuss Bologna related processes. The establishment of the teams of the HEREs in the Bologna countries was initiated by the European Commission, much like the establishment of the National TEMPUS Offices themselves.

Membership in the Ukrainian team of the HEREs is transparent. It comprises a crossclustery mixed group of individuals from the Ministry, higher education institutions, and the civil sector. It consisted of ten members in 2009-2010. The team comprised of 13 members from 2010 to 2014, and 11 members starting from 2014 (National TEMPUS Office, 2009). The interviews were conducted with the 2010-2014 membership of the team. However, most of the representatives that participated in the study are also part of the 2014 team.

The main tasks of this cross-clustery mixed team is to "participate in the development of policy and reforms' and 'work on counseling and advising higher education institutions with regard to the introduction and implementation of the national and institutional Lisbon and Bologna strategy' (National TEMPUS Office, 2009). The function of the TEMPUS Office to inform the members of the higher education sector in Ukraine about Bologna is largely enacted through the HEREs team.

At the time of data collection, the National TEMPUS Office was in the process of being renamed into the National TEMPUS/ERASMUS Plus Office. The change was triggered by the fact that the National TEMPUS Office was about to establish connections with the ERASMUS Plus. This is the program of the European Commission aimed at promoting academic mobility in the Bologna countries. This program is an extension of the ERASMUS Program, which has been supporting student exchange since 1987 in a smaller range of countries currently belonging to the EU (ERASMUS Plus Programme, 2015). Ukraine was not part of the EU, and thus, did not have the opportunity to participate in the ERASMUS 
Program. With the development of the ERASMUS Program into ERASMUS Plus, countries that do not belong to the EU like Ukraine, were invited to participate. Ukraine joined ERASMUS Plus almost right after data collection finished - in 2014. Ukraine joined this program to facilitate inward and outward academic mobility in Europe. Since the main theme of this program-academic mobility - is associated with Bologna, the coordination of this program became another task of the National TEMPUS Office. These developments triggered the change of the name of the National TEMPUS Office. It is now called the National TEMPUS/ERASMUS Plus Office (National TEMPUS Office, 2009).

This Office appears to be the civil sector actor that has been the most successful in bridging the cooperation gap and establishing close ties with the Ministry. While the TEMPUS Office does manage to convey ideas onto the Ministry, the relationship between the two actors is still not equal. The HEREs team, for instance, could be seen as being managed to an extent by the Ministry. One aspect that resonated among a number of the HEREs was related to how the Ministry participated in approving the memberships of the HEREs:

Experts from all major universities of Ukraine were suggested, and then it was the Ministry that chose people on the basis of certain criteria...the Ministry made their own corrections [in the list of experts] (i.3, HERE and a university academic staff member).

Another example of control arises when the Ministry partially limits the influence of the expertise of the HEREs in their advice on Bologna. This demonstrates how centralization persists even in the case of the partnership like this:

We learn together with other teams of HEREs at other countries... but we cooperate with the Ministry and agree our ideas with them. ...we know the politics of the country, so we should always mind what to suggest (i.2, HERE and a university vice-rector).

Thus, the National TEMPUS/ERASMUS Plus Office is successful only in facilitating the cooperation among different clusters of actors in Ukraine in Bologna. It does not fully coordinate this cooperation. 


\section{Conclusion}

This article has demonstrated that in Bologna in Ukraine the old clusters of higher education actors, and the pre-Bologna relationships amongst most of them have been partially reproduced during the Bologna reform. In particular, the Ministry of Education and Science was the most influential in higher education policy-making before Bologna. It continues to exert great control over higher education institutions, and it has remained key in directing the development of the Bologna policy instruments. In addition, there still exists a cooperation gap between the central governing bodies, represented by the Ministry, and the majority of civil sector organizations.

At the same time, this article shows that such a reproduction of the pre-Bologna actors and their relationships during the reform has been only partial. The Bologna Process has also been changing the Ukrainian higher education system by altering the relationships among some actors to an extent. Specifically, the Bologna reform has been shifting power relations within the central bodies of policy-making, allowing the Ministry of Education and Science to become the most influential amongst them. Bologna has also been promoting the enlargement of and cooperation within the civil sector, between the civil sector and higher education institutions. It has been also promoting active cooperation between at least one civil sector organization and the Ministry. The National TEMPUS/ERASMUS Plus Office has been slightly diluting the strict control of the Ministry over higher education policy-making. A gradually burgeoning and increasing cooperation among different actors, facilitated primarily by the civil sector, seems to have been accompanied by a slowly decreasing centralization in the relationships among higher education actors in Bologna.

As a result, a more horizontal policy-making in higher education in Ukraine began to emerge. Bologna has very slowly, yet steadily, been giving way to the development of a less 
centralized governance in the higher education sector in Ukraine. The findings of this research suggest that such a distributed policy-making has not yet come to replace the traditional government mode in Ukraine, as the literature on contemporary policy-making in general suggests (Enders, 2004). This literature argues that we can witness a clear shift from government to governance in policy-making practices. The particular policy setting of Ukraine, with its still quite strong dependence on the Soviet centralization legacy, indicates that the shared governing mode is only at its beginning.

\section{References}

Agasisti, T., \& Pérez-Esparrells, C. (2010). Comparing efficiency in a cross-country perspective: the case of Italian and Spanish state universities. Higher Education, 59(1), 85-103.

Bridge, G. (2004). Social policy and social work in the voluntary sector: the case of Ukraine. Social Work Education, 23(3), 281-292.

Browning, C. S., \& Christou, G. (2010). The constitutive power of outsiders: the European neighbourhood policy and the eastern dimension. Political Geography, 29(2), 109118.

Cocosatu, M. (2012). Diploma supplement - instrument of the quality assurance process in the Romanian higher education? Presented at the European Integration - Realities and Perspectives, National School of Political Studies and Public Administration (NSPSPA) - Faculty of Public Administration, Romania. Retrieved August 9, 2015, from file:///C:/Users/Ira/Downloads/SSRN-id2156879.pdf

Cusnir, S. (2008). Transferring Bologna ideas into national higher education policy practices: the case of the republic of Moldova (MSc). University of Oslo, University of Tampere, University of Aveiro, Norway, Finland, Portugal. Retrieved August 9, 
2015, from

http://www.erisee.org/downloads/library_moldova/Transffering\%20Bologna\%20Ideas \%20into\%20National\%20Higher\%20Education\%20Policy\%20Moldova\%20Republic.

pdf

Dakowska, D. (2015). Between competition imperative and Europeanisation: the case of higher education reform in Poland. Higher Education, 69(1), 129-141.

Dittrich, K., Frederiks, M., \& Luwel, M. (2004). The implementation of 'Bologna' in Flanders and the Netherlands. European Journal of Education, 39(3), 299-316.

Dobbins, M., \& Khachatryan, S. (2015). Europeanisation in the 'Wild East'? Analysing higher education governance reform in Georgia and Armenia. Higher Education, 69(2), 189-207.

Education, Audiovisual and Culture Executive Agency (EACEA), National TEMPUS Office, \& Shytikova, S. (2012, July). Document "Higher education in Ukraine.” Retrieved August 9, 2015, from http://eacea.ec.europa.eu/tempus/participating_countries/overview/ukraine_tempus_co untry_fiche_final.pdf

Enders, J. (2004). Higher education, internationalisation, and the nation-state: recent developments and challenges to governance theory. Higher Education, 47(3), 361382.

ERASMUS Plus Programme. (2015). Retrieved August 9, 2015, from http://erasmusplus.ro/?gclid=Cj0KEQjw9JuuBRC2xPG59dbzkpIBEiQAzv4G2X9H1VRkmBNofV6ehtq30zpAOxdbQX1hk6h2-XSAqAaAsfE8P8HAQ

Esyutina, M., Fearon, C., \& Leatherbarrow, N. (2013). The Bologna process in higher education: an exploratory case study in a Russian context. Quality Assurance in Education, 21(2), 145-161. 
European Higher Education Area. (2014). Retrieved August 9, 2015, from http://www.ehea.info/

Filiatreau, S. (2011). Ukraine's participation in the Bologna Process: has it resulted in more transparency in Ukrainian higher education institutions? International Research \& Review: Journal of the Phi Beta Delta H, 1(1), 1-47.

Jakobi, A. P., \& Rusconi, A. (2009). Lifelong learning in the Bologna Process: European developments in higher education. Compare: A Journal of Comparative and International Education, 39(1), 51-65.

Jones, C. (2000). Change as normality: education in Ukraine with special reference to the Crimea. In D. Coulby, R. Cowen, \& C. Jones (Eds.), Education in times of transition. London: Kogan Page.

Karveliene, R. (2014). The Bologna process and the features of implementation of the internationalization of higher education in Lithuania. Socialiniai Tyrimai/ Social Research, 2(25), 53-65.

King, C. (undated). The Bologna Process: bridge or fortress? A review of the debate from a North American perspective. Presented at the Canada-EU Bridge Project, Institute of European Studies, Institute of British Columbia. Retrieved August 9, 2015, from http://www.cceae.umontreal.ca/IMG/pdf/Conrad_King_Literature_Review.pdf

Kovacs, K. (2014). The Bologna Process in Ukraine. In T. Kozma, M. Rébay, A. Óhidy, \& É. Szolár (Eds.), The Bologna Process in Central and Eastern Europe (1. Aufl). Wiesbaden: Springer Fachmedien Wiesbaden GmbH.

Kovtun, O., \& Stick, S. (2009). Ukraine and the Bologna Process: a case study of the impact of the Bologna Process on Ukrainian state institutions. Higher Education in Europe, 34(1), 91-103. 
Kremen, V., Nikolajenko, S., Stepko, M., \& European Centre for Higher Education (UNESCO). (2006). Higher education in Ukraine. Bucharest: UNESCO-CEPES.

Kushnir, I. (2016). The development of a system of study credits in Ukraine: the case of policy layering in the Bologna Process. European Journal of Higher Education, 6(5), $1-15$.

Kuzio, T. (2012). Twenty years as an independent state: Ukraine's ten logical inconsistencies. Communist and Post-Communist Studies, 45(3-4), 429-438.

Levada, I. (2008). Elite structures in the Soviet and post-Soviet situation: the sociology of Iurii Levada [Editorial introduction]. Sociological Research, 47(6), 29-46.

Luhovy, V., \& Kalashnikova (Eds.). (2014). Pravovi zasadu realizaciyi Bologskogo Protsesu $v$ Ukrayini [Legal basis of the implementation of the Bologna Process in Ukraine]. Kyiv: DP NVTS Prioritety. Retrieved August 9, 2015, from http://www.irf.ua/knowledgebase/publications/pravovi_zasadi_realizatsii_bolonskogo _protsesu_v_ukraini/

Malle, S. (2009). Soviet legacies in post-Soviet Russia: insights from crisis management. Post-Communist Economies, 21(3), 249-282.

Melikyan, H. (2011). Education reforms in the republic of Armenia and the Bologna Process: brief overview (Author's personal opinion). Bulgaria: the University of Ruse. Retrieved August 9, 2015, from http://webcache.googleusercontent.com/search?q=cache:dgmAZPkdzzMJ:www.erasm usmundus5.gr/scientific/Education_Reforms_in_the_RA_and the_Bologna_Process.d $\underline{\mathrm{oc}+\& \mathrm{~cd}=3 \& \mathrm{hl}=\mathrm{en} \& \mathrm{ct}=\mathrm{clnk} \& \mathrm{gl}=\mathrm{ua}}$

National TEMPUS Office. (2009). Retrieved August 9, 2015, from http://www.tempus.org.ua/en/contacts.html 
Protsyk, O. (2003). Domestic political institutions in Ukraine and Russia and their responses to EU enlargement. Communist and Post-Communist Studies, 36(4), 427-442.

Pshenychna, L. V. (2009). Derzhavne spryyannya adaptatsiyi systemy vyshchoyi osvity v Ukrayini do vymoh Bolonskogo Protsesu [State assistance in the adaptation of higher education system in Ukraine to the requirements of the Bologna Process] (Candidate of Scinces). Kharkiv Regional Institute of State Management, Kharkiv, Ukraine. Retrieved August 9, 2015, from http://www.irbis-nbuv.gov.ua/cgibin/irbis_nbuv/cgiirbis_64.exe

Pyykkö, R. (2008). Bachelors for Europe, specialisty for the fatherland: Bologna through Russian eyes. Slavica Helsingiensia, 35, 331-337.

Shaw, M. (2013). Flawed implementation or inconsistent logics? Lessons from higher education reform in Ukraine. European Education, 45(1), 7-24.

Shestavina, S. (2004). Interaction of Ukrainian educational policy and the EU neighbourhood policy in the context of the Bologna Process. In F. Attina \& R. Rissi (Eds.), European Neighbourhood Policy: political, economic, and social issues. Cantania, Italy: The Jean-Monnet Centre 'Euro-Med,' University of Catania.

Smyrnov, O. (2013, January 20). Analiz zakonoproektu Kivalova-Tabachnyka. Dezhavyu ta plagiat [The analysis of the draft Law by Kivalov-Tabachnyk. Déjà vu and plagiarism] [Official website of the Ukrainian Association of Students' Self-Government]. Retrieved August 9, 2015, from http://www.uass.org.ua/index.php/analytics/536kivalovproject

Telpukhovska, V. (2006). Bologna Process in the national context of Ukraine - tribute or fashion or necessary step (Master's). University of Tampere, Finland. Retrieved August 9, 2015, from https://tampub.uta.fi/bitstream/handle/10024/94036/gradu01456.pdf?sequence=1 
Thelen, K. (2003). How institutions evolve: insights from comparative historical analysis. In J. Mahoney \& D. Rueschemeyer (Eds.), Comparative historical analysis in the social sciences. Cambridge, U.K.; New York: Cambridge University Press.

Tsygankov, A. P. (2007). Modern at last? Variety of weak states in the post-Soviet world. Communist and Post-Communist Studies, 40(4), 423-439.

Vukasovic, M. (2013). Change of higher education in response to European pressures: conceptualisation and operationalisation of Europeanisation of higher education. Higher Education, 66(3), 311-324.

Witte, J. K. (2006). Change of degrees and degrees of change: comparing adaptations of European higher education systems in the context of the Bologna process. CHEPS, Centre for Higher Education Policy Studies, Enschede. Retrieved August 9, 2015, from http://www.che.de/downloads/C6JW144_final.pdf

Wodak, R., \& Fairclough, N. (2010). Recontextualising European higher education policies: the cases of Austria and Romania. Critical Discourse Studies, 7(1), 19-40.

Wolczuk, K. (2009). Implementation without coordination: the impact of EU conditionality on Ukraine under the European Neighbourhood Policy. Europe-Asia Studies, 61(2), $187-211$. 


\section{Appendix 1 - List of interviewees}

1. Academic staff member at university;

2. Higher education reform expert at the National TEMPUS office, vice-rector at university;

3. Higher education reform expert at the National TEMPUS office, university academic staff member;

4. National TEMPUS Office representative;

5. Ex-member of a working group of the Parliamentary Committee of Education and Science Matters, ex-member of the Bologna Follow-up Group, head of department at university;

6. Representative of the Department of Higher Education in the Ministry, member of the Bologna Follow-up Group, Higher education reform expert at the National TEMPUS office, ex-member of the Scientific Advisory Centre;

7. Ex-member of the Bologna Follow-up Group, vice-rector at higher education institution F, ex-representative of the Department of Higher Education at the Ministry;

\section{Appendix 2 - Policy documents}

\section{Documents of the central governing bodies:}

\section{a. National Bologna implementation reports}

National Bologna implementation report. (2004, September 16). Retrieved August 9, 2015, from http://www.ehea.info/Uploads/Documents/National_Report_Ukraine_05.pdf

\section{b. State documents}

Constitution of Ukraine. (1996). Retrieved August 9, 2015, from http://zakon4.rada.gov.ua/laws/show/254\%D0\%BA/96-\%D0\%B2\%D1\%80

Draft law about higher education №1187. (2012, December 28). Retrieved August 9, 2015, from http://w1.c1.rada.gov.ua/pls/zweb2/webproc4_1?pf3511=45287

Draft law about higher education №1187-1. (2013, January 11). Retrieved August 9, 2015, from http://w1.c1.rada.gov.ua/pls/zweb2/webproc4_1?pf3511=45439

Draft law about higher education №1187-2. (2013, January 21). Retrieved August 9, 2015, from http://w1.c1.rada.gov.ua/pls/zweb2/webproc4_1?pf3511=45512

Draft law about higher education №7486-1. (2010, December 22). Retrieved August 9, 2015, from http://w1.c1.rada.gov.ua/pls/zweb2/webproc4_1?pf3511=39329

Draft law about higher education №9655. (2011, December 28). Retrieved August 9, 2015, from http://w1.c1.rada.gov.ua/pls/zweb2/webproc4_2?id=\&pf3516=9655\&skl=7 
Draft law about higher education №9655-1. (2011, December 30). Retrieved August 9, 2015, from http://w1.c1.rada.gov.ua/pls/zweb2/webproc4_2?id=\&pf3516=9655-1\&skl=7

Draft law about higher education №9655-2. (2012, January 6). Retrieved August 9, 2015, from http://w1.c1.rada.gov.ua/pls/zweb2/webproc4_1?pf3511=42264

Governmental resolution №82 “About the creation of the Interdepartmental Commission to support the Bologna Process in Ukraine." (2006, February 1). Retrieved August 9, 2015, from http://zakon4.rada.gov.ua/laws/show/82-2006-\%D0\%BF

Governmental resolution №180 “About the liquidation of certain consultative, advising and other additional bodies, created by the Cabinet of Ministers of Ukraine." (2013, March 13). Retrieved August 9, 2015, from http://zakon4.rada.gov.ua/laws/show/180-2013$\% \mathrm{D} 0 \% \mathrm{BF}$

Governmental resolution №1225 "About the creation of the interdepartmental group for the creation and implementation of the national framework of qualifications." (2010, December 29). Retrieved August 9, 2015, from http://zakon4.rada.gov.ua/laws/show/1225-2010-\%D0\%BF

Law about higher education. (2002). Retrieved August 9, 2015, from http://zakon4.rada.gov.ua/laws/show/2984-14

Law about higher education. (2014). Retrieved August 9, 2015, from http://zakon4.rada.gov.ua/laws/show/1556-18

Law about international agreements. (2004). Retrieved August 9, 2015, from http://zakon4.rada.gov.ua/laws/show/1906-15

Ministerial decree №48 “About a pedagogical experiment on the credit-module system of the organisation of the study process." (2004, January 23). Retrieved August 9, 2015, from https://www.google.com.ua/url? sa=t\&rct=j\&q=\&esrc=s\&source=web\&cd=1\&cad=rja \&uact=8\&ved=0CBwQFjAAahUKEwj_mt_asZzHAhVGVSwKHVGhDWY\&url=htt p\%3A\%2F\%2Fold.mon.gov.ua\%2Fimages\%2Ffiles\%2Fosvita\%2FEvrointehraciya\% 2Fmon_48.doc\&ei $=\mathrm{cXvHVb}$ eG8aqsQHRwrawBg\&usg=AFQjCNF4jX4JOyHhKQ1TZWAV7KuMWY14kA\&sig2 =HQXI36SqDiVMGZY2_h48Hw\&bvm=bv.99804247,d.bGg

Ministerial decree №49 “About the confirmation of the programme of actions related to the implementation of the ideas of the Bologna declaration in the system of higher education and science of Ukraine for 2004-2005." (2004, January 23). Retrieved August 9, 2015, from https://www.google.com.ua/url?sa=t\&rct=j\&q=\&esrc=s\&source=web\&cd=1\&cad=rja \&uact=8\&ved=0CBwQFjAAahUKEwiynZ6OuZzHAhVBjCwKHbSLCp4\&url=http $\% 3 \mathrm{~A} \% 2 \mathrm{~F} \% 2 \mathrm{Fiic}$.dgtu.donetsk.ua\%2Frussian\%2Fovs\%2Fprik_2.doc\&ei=NIPHVbKz HcGYsgG016rwCQ\&usg=AFQjCNEsSfBYF3OtAhEBWjmzNN7gTSlAA\&sig2=u4Im-FkySjOMepLF6i4JA\&bvm=bv.99804247,d.bGg

Ministerial decree №943 “About the implementation of the European credit-transfer system at higher educational establishments of Ukraine ." (2009, October 16). Retrieved August 
9, 2015, from http://www.abiturient.in.ua/ua/bologna_process_ua/nakaz_943_ua

National doctrine of education development. (2002, April 17). Retrieved August 9, 2015, from http://zakon4.rada.gov.ua/laws/show/347/2002

Parliamentary resolution №27 “About the membership of Ukraine in the European Cultural Convention of 1954." (1994). Retrieved August 9, 2015, from http://zakon4.rada.gov.ua/laws/show/4030-12

\section{Bologna international documents}

Bergen communique. (2005, May 19). Retrieved August 9, 2015, from http://www.ehea.info/Uploads/Declarations/Bergen_Communique1.pdf

Berlin communique. (2003, September 19). Retrieved August 9, 2015, from http://www.ehea.info/Uploads/Declarations/Berlin_Communique1.pdf

Bologna declaration. (1999, June 19). Retrieved August 9, 2015, from http://www.magnacharta.org/resources/files/BOLOGNA_DECLARATION.pdf

Education, Audiovisual and Culture Executive Agency (EACEA), National TEMPUS Office, \& Shytikova, S. (2012, July). Document "Higher education in Ukraine." Retrieved August 9, 2015, from http://eacea.ec.europa.eu/tempus/participating_countries/overview/ukraine_tempus_co untry_fiche_final.pdf

\section{Documents of the civil sector (the National TEMPUS Office)}

National TEMPUS Office. (2009). "Directions for the work of the Higher Education Reform Experts for 2010-2011.” Retrieved August 9, 2015, from http://www.tempus.org.ua/uk/national-team-here/90--here.html 